\title{
Sonda environmentální gramotnosti studentů přírodovědně a ekologicky zaměřených oborů na Pedagogické fakultě JU
}

\author{
Simona Dvořáčková, Renata Ryplová \\ Envigogika 2012/VII/3- Recenzované články/ Reviewed Papers \\ Publikováno/Published 31 12. 2012 \\ DOI: http://dx.doi.org/10.14712/18023061.77
}

\begin{abstract}
Abstrakt:
Příspěvek analyzuje výsledky sondy environmentální gramotnosti studentů prvního až třetího ročníku dvou bakalářských studijních oborů na katedře biologie Pedagogické fakulty Jihočeské univerzity ( $P F \quad J U$ ) - Př́rodopis se zaměřením na vzdělávání (PU) a Př́rodovědná a ekologická výchova (PEV). Sonda je pilotním pokusem pro ověření možnosti testování některých aspektů environmentální gramotnosti pomocí indikátorů vycházejících z dokumentu Doporučené a očekávané výstupy (DOV) pro základní vzdělávání (Pastorová a kol., 2011a, 2011b). Odpovědi studentů byly zpracovány do kategorií: Vztah k př́rodě, Zákonitosti, Proenvironmentální chování a Výzkumné dovednosti. v oblasti "Výzkumné dovednosti" byl sledován zejména vliv tzv. badatelsky orientovaného vyučování (BOV), které je $v$ současné době na katedře biologie PF JU aktivně uplatňováno. $Z$ analýzy výsledků je patrné, že studenti obou bakalářských oborů mají srovnatelnou úroveň environmentální gramotnosti. Zaznamenané rozdíly v oblastech "Zákonitosti" a "Výzkumné dovednosti", ve kterých si vedou lépe studenti PU, reflektují odlišnosti $v$ obsahu a zaměření studijních programů. Lepší výsledky studentů PU $v$ oblasti "Výzkumné dovednosti" jsou zřejmým př́nosem badatelsky orientovaného vyučování (BOV), se kterým se studenti PU setkávají ve větší míře než studenti PEV. Sonda však také naznačila, že výsledky mohou být ovlivněny i některými dalšími intervenujícími faktory, jako je např́klad absolvovaný typ střední školy.
\end{abstract}

\section{Klíčová slova:}

BOV, environmentální výchova, Doporučené očekávané výstupy

\begin{abstract}
:
This article presents the results of an environmental literacy pre-test conducted among first to third year students of two Bachelor study programmes at the Department of Biology, Faculty of Education, at the University of South Bohemia (PF JU) - the Introductory Teacher Training course in Natural History (PU) and Nature and Environmental Education (PEV). The test is an initial attempt to probe alternatives for testing some aspects of environmental literacy using variables based on the curriculum document Recommended Objectives for Environmental Education (Pastorová a kol., 2011a, 2011b). Students' responses were analysed in four categories: relationship to nature, knowledge of ecological principles, proenvironmental behavior and investigative skills. In the area of investigation skills, the main focus was placed on the effect of Inquiry-Based Science Education (IBSE), which is being actively implemented at the Department of Biology PF JU. The results show that students of both programmes have a comparable
\end{abstract}


level of environmental literacy. Significant differences were noted only in the categories 'knowledge of ecological principles' and 'investigative skills', in which PU students scored better. This could reflect differences in the content and focus of both programmes. Th ebetter results of PU students in the area of 'investigative skills' is also attributed to Inquiry-Based Science Education, which is applied in more PU subjects compared to PEV. The test also indicated that some other intervening variables could influence the results, such as the type of previous education the students' experienced.

\section{Key words:} Education

IBSE, environmental education, Recommended Objectives for Environmental 


\section{Úvod}

Testování environmentální gramotnosti žáků a studentů je v rámci environmentální výchovy nezbytné pro zjištění kvality a efektivity výuky. U studentů pedagogicky zaměřených vysokoškolských oborů je zjištování úrovně environmentální gramotnosti zároveň nezbytnou informací k posouzení jejich potenciálu správně uchopit jednotlivá témata environmentální výchovy $v$ jejich předpokládaném budoucím pưsobení v pedagogické praxi. Jak uvádí např. Cheng a Monroe (2010), právě vliv př́rodovědně vzdělaných pedagogických pracovníků hraje v environmentální výchově školní mládeže zásadní roli.

Problematika testování environmentální gramotnosti je poměrně složitým a často diskutovaným tématem (např. Činčera, 2004; Činčera a Štěpánek, 2007). v zahraničí se k tomuto účelu používá několik rozdílných metodik (přehled viz Činčera a Stěpánek, 2007), z nichž některé již byly testovány i v českém prostředí (např. Soukup, 2001; Franěk, 2012). Výsledky těchto studií však naznačují, že použití některých $v$ zahraničí všeobecně uznávaných nástrojů $v$ českém prostředí se $v$ některých aspektech jeví jako problematické (Franěk, 2012). Zahraniční metodiky vycházejí z tamního pojetí a školních legislativ environmentální výchovy, které se od českého mnohdy významně odlišuje. v České Republice byl v roce 2011 přijat dokument" Doporučené očekávané výstupy (Pastorová a kol., 2011a, 2011b), jímž jsou specifikovány očekávané výstupy prǔřezového tématu environmentální výchova $\mathrm{V}$ RVP. Doposud však nebyl vyvinut sofistikovaný evaluační nástroj, odrážející specifika českého pojetí environmentální výchovy, který by umožňoval v souladu s tímto dokumentem úroveň dosažené environmentální gramotnosti hodnotit. Následující článek přináší výsledky pilotní sondy některých aspektů environmentální gramotnosti, která byla vedena snahou reflektovat $v$ hodnocení environmentální gramotnosti právě klíčové oblasti DOV. Cílem sondy tedy nebylo vlastní vytvoření testovacího nástroje, nýbrž pouze prvotní ověření možností pro jeho tvorbu a reflexe získaných poznatků.

Sonda byla provedena na katedře biologie PF JU mezi studenty dvou bakalářských oborů: Přírodopis se zaměřením na vzdělání (PU) a Přírodovědná a ekologická výchova specializace $v$ pedagogice (PEV). Studenti bakalářského studia PU mohou pokračovat v navazujícím magisterském studiu Učitelství prírodopisu pro 2 . stupeň ZŠ a tudíž se u nich předpokládá pozdější pedagogické pưsobení v oblasti školního vzdělávání mládeže. u absolventů oboru PEV se předpokládá jejich působení především v rámci mimoškolní a mimotřídní výchovy dětí na pozicích odborných lektorů přírodovědně zaměřených kroužků, center ekologické výchovy či asistentů učitelů zš.

Sonda vycházela z predpokladu, že absolventi obou dvou studijních oborů mohou ve své pozdější praxi významně ovlivnit školní i mimoškolní environmentální výchovu mládeže. $v$ rámci sondy bylo zjištováno, zda mezi testovanými obory existuje rozdíl $v$ některých environmentálních kompetencích a jakým způsobem Ize uvažované indikátory nejlépe sledovat.

Hlavním cílem provedeného průzkumu uskutečněného na poměrně malé skupině respondentů byla tvorba návrhu testování a výběr vhodných indikátorů. Snahou autorek bylo přispět $k$ vytvoření metodiky komplexního hodnocení environmentální gramotnosti $\checkmark$ českém prostředí založeného na pojetí DOV, přinést prvotní poznatky z terénního šetření a inspiraci pro budoucí dlouhodobější a obsáhlejší průzkum.

Dalším z cílů průzkumu bylo také sledování vlivu tzv. badatelsky orientovaného vyučování (BOV) na environmentální gramotnost studentů, jež je v posledních letech na katedře biologie PF JU aktivně podporována. BOV ( $z$ angl. IBSE - Inquiry-Based Science Education) je novým trendem ve výuce biologie, který byl s úspěchem aplikován již v řadě zemí EU iv USA a jeví se jako jedno z možných východisek současné krize v přirodovědném vzdělání (Evropská komise, 2007; Osborne a Dilon, 2008). Název Ize volně přeložit jako učení objevováním. 
Pojem badatelsky orientovaného vyučování charakterizuje např. Papáček (2010), jako jednu z účinných aktivizujících metod problémově orientovaného učení, kdy učitel nepředává učivo výkladem v hotové podobě, ale vytváří znalosti cestou řešení problému a systémem kladených otázek.

V rámci řešení učitelem nastolených problémů se žáci učí formulovat výzkumné otázky, promýšlet a navrhovat metodické postupy řešení problémů, plánovat experimenty, získávat, zaznamenávat a interpretovat data, vyvozovat závěry apod. - tedy nenásilnou formou se seznamují s vědeckým postupem řešení problémů. Vhodnost využití BOV v environmentální výchově rozebírá např. Forbes a kol. (2011). Badatelsky orientovaná výuka mưže být podle Ye a kol. (2008) přínosná také pro vzdělání pro trvale udržitelný rozvoj, či podle Michaelse a kol. (2008) pro řešení problémů současného světa v globálním měřítku. Pilotní průzkumy implementace BOV do výuky přírodopisu na ZŠ prováděné na katedře biologie PF JU již přinášejí informace o pozitivním vlivu BOV na environmentální výchovu žáků (Ryplová a Reháková, 2011).

\section{Metodika}

Celkem bylo testováno 97 studentů prvních až třetích ročníků denního studia, z toho 18 studentů oboru Přírodovědná a ekologická výchovy (PEV) a 79 studentů Přírodopis se zaměřením na vzdělávání (PU). Mezi respondenty nebyl uplatňován žádný užší výběr, průzkum zahrnoval všechny studenty jednotlivých ročníků a studijních skupin přítomné ve výuce. Vzhledem k rozdílnému počtu studentů $v$ jednotlivých ročnících a oborech jsou bohužel $v$ počtu respondentů jednotlivých testovaných skupin značné rozdíly, což představuje jeden z limitů tohoto průzkumu a některé výsledky Ize proto považovat pouze za orientační.

Oba bakalářské obory vyučované na katedře biologie PF JU (PU i PEV) mají v prvním ročníku společný základ, po kterém posluchači absolvují přednášky speciálně koncipované pro předpokládané potřeby pozdější praxe. Společný základ prvního ročníku se věnuje tématům neživé prírody a ekologii. Některé další předměty jsou probírány $v$ obou studijních oborech, ale v různých ročnících a s různým akcentem, jiné jsou specifické pouze pro daný obor. Např́klad předměty týkající se morfologie, ontogeneze, fyziologie, a anatomie jsou v programu PU probírány ve větším rozsahu než v programu PEV. Na druhou stranu program PEV je posílen o předměty z oblasti společenských věd (filozofie, psychologie, pedagogika), z chovatelství, pěstitelství, či ochrany životního prostředí. Další rozdíly $v$ obsahu studia jsou zapříčiněny možností volitelných předmětů, které si studenti obou studijních oborů vybírají na základě svých preferencí.

Sonda byla realizována formou komplexního dotazníku (přiloha), ve kterém se střídaly otevřené i uzavřené otázky, otázky s možností výběru odpovědi a přiřazování správných odpovědí ( $v$ tomto případě pořadí). Předlohou pro některé otázky použité v dotazníku je průzkum environmentální gramotnosti studentů středních škol provedený Činčerou a Štěpánkem (2007) a obdobné průzkumy prováděné v zahraničí (např. Yavetz et al., 2009). Test se skládal z 5 částí, (a - e), které byly koncipovány tak, aby odpovědi umožnily interpretaci některých klíčových témat odpovídajících oblastem DOV (Činčera, 2011), vlivu BOV a pozad'ových dat:

\section{(a) Pozad'ová data - absolvovaný typ střední školy}

Lze předpokládat, že na stupeň environmentální gramotnosti a charakter proenvironmentálního chování studentů může mít vliv mnoho faktorů (například sociální a ekonomické zázemí, místo bydliště, či osobnost dotazovaných). Ve volbě uchazečů o studium mohou hrát významnou roli rozdíly v kurikulech a uplatněních obou testovaných oborů, respektive do jednotlivých oborů se mohou hlásit studenti s odlišnými zájmy a orientací středního vzdělání. Absolvované středoškolské vzdělání pak mưže mít vliv na míru environmentální gramotnosti, hlavně v prvních ročnících (Barraza, 1999; Korhonen, 
2004). Z tohoto důvodu byl zjištován $v$ první části testu také typ absolvované střední školy.

\section{(b) Vztah k přírodě}

Sledovaný indikátor Vztah k přírodě vychází z DOV, oblasti nazvané environmentální senzitivita, která by podle dokumentu měla vyjadřovat " citlivost, vztah a empatii vưči prírodě a životnímu prostředí, včetně citlivého vztahu ke zviŕatưm a rostlinám" (Pastorová a kol., 2011a). Jedná se o velmi těžko měřitelnou veličinu.

Hodnocení environmentální senzitivity i vlastní vymezení tohoto pojmu je velmi problematickým a často diskutovaným tématem (shrnutí viz Činčera, 2011). Otázky $\mathrm{k}$ hodnocení vztahu $\mathrm{k}$ prírodě $\mathrm{v}$ tomto výzkumu byly po úvaze vybrány tak, aby odrážely dvě nejčastěji se objevující kategorie: míru interakce s př́rodou (Sivek, 2002) a tzv. "Significant life experiences" (SLE), (např. Chawla, 1999, Vadala a kol., 2007).

Míra vztahu k př́rodě byla zjištována z počtu a typu chovaných zviŕat a z frekvence pobytu $v$ př́rodě. Je možné předpokládat, že péčí o domácí zviřre se člověk dostává nejen do úzkého kontaktu s př́rodou, ale zároveň se v něm rozvíjí schopnost empatie, vztah a starostlivost o živé tvory, poznávání základních principů fungování přírody (jako je látkový př́jem a výdej, růst a vývoj, reakce na změny externích podmínek) a umožňuje nabývání pozitivních, ale i negativních zkušeností (Jančaříková, 2009).

Pozitivní vliv délky pobytu $v$ prrírodě na vztah $\mathrm{k}$ ní je $\mathrm{v}$ literatuře široce diskutován (Chawla, 1999; Vadala a kol. 2007). Pro posouzení frekvence návštěv za účelem kvalitního a aktivního pobytu $\vee$ prírodě byli respondenti dotazováni na frekvenci vycházek / výletů, pro jejíž záznam byla použita 10-ti bodová škála (10 bodů - několikrát denně, 9 bodů každý den, 8 bodů - několikrát týdně, 7 bodů - jednou týdně, 6 bodů - několikrát měsíčně, 5 bodů - jednou měsićně, 4 body - několikrát do roka, 3 body - jednou za rok, 2 body několikrát $v$ životě, 1 bod - nikdy). Desetibodová škála umožňuje detailnější sebereflexi týkající se množství stráveného času $v$ př́rodě. Míra vztahu $\mathrm{k}$ přírodě byla hodnocena součtem počtu dosažených bodů za množství času $v$ přírodě a počtu chovaných druhů zviŕat (za každý druh získal respondent 1 bod).

\section{(c) Proenvironmentální chování}

Část testu hodnotící proenvironmentální chování je založena na klíčové oblasti DOV "Akční strategie", která koresponduje se "znalostmi a dovednostmi, které vedou k odpovědnému environmentálnímu jednání" (Pastorová a kol., 2011a), jež v domácím prostředí souvisí převážně se spotřebitelstvím (Činčera, 2011). Míra proenvironmentálního chování, nikoliv jen teoretických postojů a názorů, byla hodnocena podle frekvence konání vybraných činností, u kterých se předpokládá, že vyjadřují kladný vztah k životnímu prostředí. Do dotazníku bylo vybráno pět činností, které byly formulovány na základě podobných průzkumů provedených $v$ minulosti (např. Činčera a Štěpánek, 2007): dotaz byl položen tak, aby umožnil zaznamenat, jak často respondenti: tříí odpad, kupují výrobky označené jako EKO a BIO, upřednostňují koupi českých výrobků před zahraničními, či se účastní proenvironmentálních akcí. Bodování frekvence těchto aktivit proběhlo na škále od 10 do 1 (10 bodů - několikrát denně, 9 bodů - každý den, 8 bodů několikrát týdně, 7 bodů - jednou týdně, 6 bodů - několikrát měsičně, 5 bodư - jednou měsičně, 4 body - několikrát do roka, 3 body - jednou za rok, 2 body - několikrát v životě, 1 bod - nikdy). Desetibodová škála byla záměrně zvolena proto, aby umožnila co nejpřesněji vyhodnotit frekvenci jednání, a to i z dlouhodobého hlediska (zmapovat i aktivity, které mohly být vykonány $v$ minulosti pouze jednou). Zároveň ale také umožňuje respondentům vyjádřit některé př́íklady velmi častého jednání (například, když student vypije během dne několik nápojů $V$ PET lahvích, které pokaždé odhodí do odpadkového koše určeného pro plasty, nebo když se při nákupech a stravování zaměřuje na české či BIO výrobky). Míra proenvironmentálního chování byla dána součtem dosažených bodů. 


\section{(d) Zákonitosti}

Pozitivní vztah mezi znalostmi a proenvironmentálním chováním byl sledován v mnoha průzkumech (např.: Hsu, 2004; McMillan et al., 2004). Metodický dokument DOV odkazuje na znalosti v klíčovém tématu "Zákonitosti", které jsou pojímány jako: "znalosti základních principů fungování prostředí ... jako je napríklad tok energie a koloběh látek..., potravní řetězce..., vztahy mezi organismy a prostředím..., sociální struktura populací a společenstev..., či antropogenní vliv na prostředí..." (Pastorová a kol., 2011a). Pro testování znalostí o zákonitostech byly položeny celkem tři otevřené otázky, jejichž cílem bylo zjistit vnímání základních vztahů mezi biotickou a abiotickou složkou životního prostředí a prokázat tak znalost základních faktů, ale i schopnost systémového vnímání. Chybné odpovědi byly vyřazeny, správné pak byly rozčleněny do několika kategorií a dále analyzovány.

Otázka analyzující znalosti vztahů mezi rostlinou a atmosférou postihuje jeden ze základních ekologických problémů současné doby - globální změny atmosféry a roli rostlin $v$ tomto problému. Cílem bylo zjistit, zda studenti vnímají projevy základních fyziologických dějů u rostlin $v$ dynamickém vztahu $\mathrm{s}$ jejich životním prostředím představovaném $v$ tomto případě atmosférou. Vztah mezi rostlinami a atmosférou je všeobecně vnímán především z pohledu vlivu globálního oteplování a rostoucí hladiny $\mathrm{CO}_{2}$ na fyziologické procesy $\checkmark$ rostlinách. Vliv životních projevů rostlin na stav atmosféry pak bývá chápán především $v$ souvislosti se snižováním množství $\mathrm{CO}_{2}$ v atmosfére díky jeho fotosyntetické fixaci do rostlinných tkání a zabudování uhlíku do rostlinné biomasy. Široká veřejnost je však již podstatně méně informována o dalších vlivech rostlin na dění $v$ atmosféře. Významná je tak např́ílad i "chladící" role rostlin $v$ mikroklimatu stanoviště díky probíhající rostlinné transpiraci (např. Bowler a kol., 2010, Pokorný a kol., 2010, Kravčík a kol., 2008), pohlcování prachových částic rostlinami (např. Fowler a kol., 2009) a především rostlinné emise těkavých organických látek, (BVOC), které např. $v$ městském ovzduší znečištěném imisemi přispívají ke vzniku škodlivého troposférického ozonu (Smiatek a Steinbrecher, 2006) a jejichž prủměrná roční globální světová produkce je několikanásobně vyšší, než produkce těchto těkavých organických látek pocházejících $\mathrm{z}$ antropogenních zdrojů (Guenther a kol., 1995). Znalost těchto zákonitostí u budoucích učitelů i pracovníků v mimoškolní výchově, kteří svým budoucím aktivním pedagogickým působením mohou přispět ke zvýšení všeobecné informovanosti o této problematice, je tedy velmi důležitá.

Testována byla i znalost vlivu člověka na neživou přírodu. Vztah mezi člověkem a neživou složkou prírody býval velmi často ve školství opomíjen v pojetí klasické výuky, kde se geologie a geologické procesy učí většinou samostatně a bez souvislostí s ostatními složkami životního prostředí. Malá rychlost geologických procesů a často opožděná reakce na změny vyvolané biotickou složkou vedou k názoru, že geologické procesy jsou jen nepatrně, nebo vůbec, ovlivněny činností rostlin, živočichů a člověka. Otázka byla zaměřena na antropogenní vliv na urychlení eroze hornin záměrně, aby studenti ukázali svou vnímavost na dopad lidského chování.

Řada odborníků volá $v$ současné době po změně v procesu rozvíjení kognitivních schopností žáků ve smyslu potřeby pojímat studium přírodních zákonitostí v širších souvislostech nejen ekologických, ale i společenských, technologických a ekonomických. Tedy $v$ souvislosti s tzv. trvale udržitelným rozvojem (např. Lubezki a kol., 2004; Zoller, 2012). Mají-li žáci vnímat př́rodní zákonitosti v kontextu trvale udržitelného rozvoje, musí chápat význam tohoto pojmu. Proto byla do výzkumu zařazena i otázka zjišt́ující, zda respondenti chápou pojem „Trvale udržitelný rozvoj" v jeho původním slova smyslu.Stejně jako předchozí otázky $v$ této sekci, byla i tato analyzována pomocí kódování odpovědí do kategorií, z nichž byly započítávány pouze ty relevantní.

\section{(e) Výzkumné dovednosti}

Klíčové téma Výzkumné dovednosti a znalosti, je podle DOV charakterizováno jako "schopnosti žáků samostatně zkoumat environmentální problémy a konflikty a vyhodnocovat jejich možná řešení" (Pastorová a kol. 2011a). Svým vymezením je toto 
klíčové téma blízké tzv. badatelskému pojetí výuky (BOV), které je v současné době na katedře biologie PF JU aktivně uplatňováno.

Studenti oboru PU se s problematikou BOV setkávají v průběhu studia ve větší míre než studenti oboru PEV. Řada vyučujících využívá toto pojetí výuky $v$ přednáškách a cvičeních, studenti oboru PU zpracovávají bakalářské práce s tématikou BOV. k posouzení vlivu BOV na stupeň výzkumných znalostí a dovedností byla zaměřena testová otázka, ve které měli studenti správně seřadit 9 etap vědeckého postupu experimentu.

\section{Statistická analýza:}

Získaná data byla statisticky zpracována $v$ programu Excel a rozdíly mezi jednotlivými studijními skupinami byly zjištovány pomocí Studentova t- testu. Vzhledem $\mathrm{k}$ malému počtu respondentů $v$ některých skupinách nemohly být prováděny hlubší statistické analýzy.

\section{Výsledky}

\section{(a) Absolvovaný typ středoškolského vzdělání}

Z výsledků vyplývá, že studenti PU jsou většinou absolventy gymnázií, středních pedagogických škol a středních zdravotnických škol. Studenti oboru PEV přicházejí převážně ze středních ekologických škol a středních zemědělských škol, v malé míře z gymnázií, zdravotnických nebo obchodních škol (výjimku tvoří pouze 3. ročník PEV, kde většina studentů absolvovala gymnázium) - viz obr. 1.

\section{Střední vzdělání}

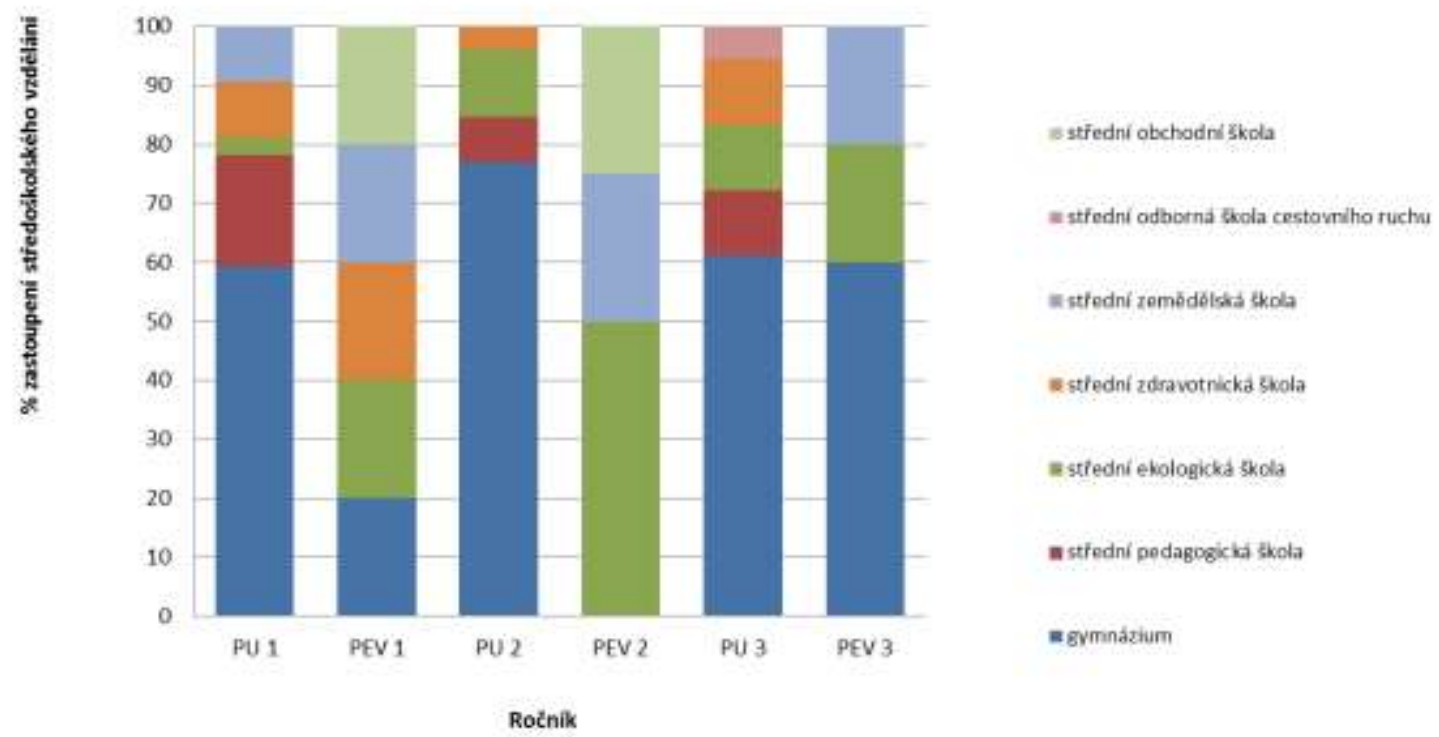

Obr. 1. Zastoupení jednotlivých typů absolvovaných středních škol u studentů bakalářských oborů na katedře biologie PF JU. 


\section{(b) Vztah k př́ŕodě}

Studenti obou sledovaných skupin v průměru chovají, nebo $v$ minulosti chovali, pět druhů zviŕă na osobu (obr. 2a). Mezi oběma sledovanými skupinami (PEV a PU) nebyly zjištěny statisticky významné rozdíly v počtu chovaných zviřat. z celého počtu 97 respondentů se našlo pouze šest, kteří nikdy žádná zvíraata nechovali: dva ve druhém ročníku PEV, dva ve druhém ročníku PU a dva ve třetím ročníku PU. $z$ analýzy chovaných druhů vyplynulo, že studenti nejčastěji chovali psy, kočky a rybičky. Na druhém místě se umístily slepice a králíci, poté drobné ptactvo a křečci. Velmi často byla chována prasata, ovce, skot a kachny. Žádný markantní rozdíl $v$ druzích chovaných zviřat mezi studijními obory nebyl zjištěn, kromě poznatku, že studenti PU prvního ročníku chovali ve větší míře i méně obvyklé druhy, jako tropické žáby, chameleony, činčily, fretky, africké šneky či suchozemské želvy.

Celkově mezi obory PEV a PU nebyly zjištěny statisticky významné rozdíly $v$ průměrném objemu času tráveného $v$ př́rodě (obr. 2b). Také mezi jednotlivými studijními skupinami jsou jen malé a statisticky nevýznamné rozdíly. Nejvíce průměrného času $v$ prrírodě trávili studenti třetího ročníku PEV (téměř každý den), a nejméně studenti druhého ročníku PEV (méně než několikrát týdně). Počet chovaných zvírat u respondentů koreluje $s$ délkou pobytu $v$ prírodě, jak uvádí obr. č. 2c. s nárůstem počtu chovaných druhů zviŕat na osobu mírně narưstá také objem času stráveného v přírodě. Pomocí lineární regrese byla zjištěna závislost mezi délkou pobytu $v$ prírodě a počtem chovaných druhů u všech dotazovaných studentů $(R=0,392)$.
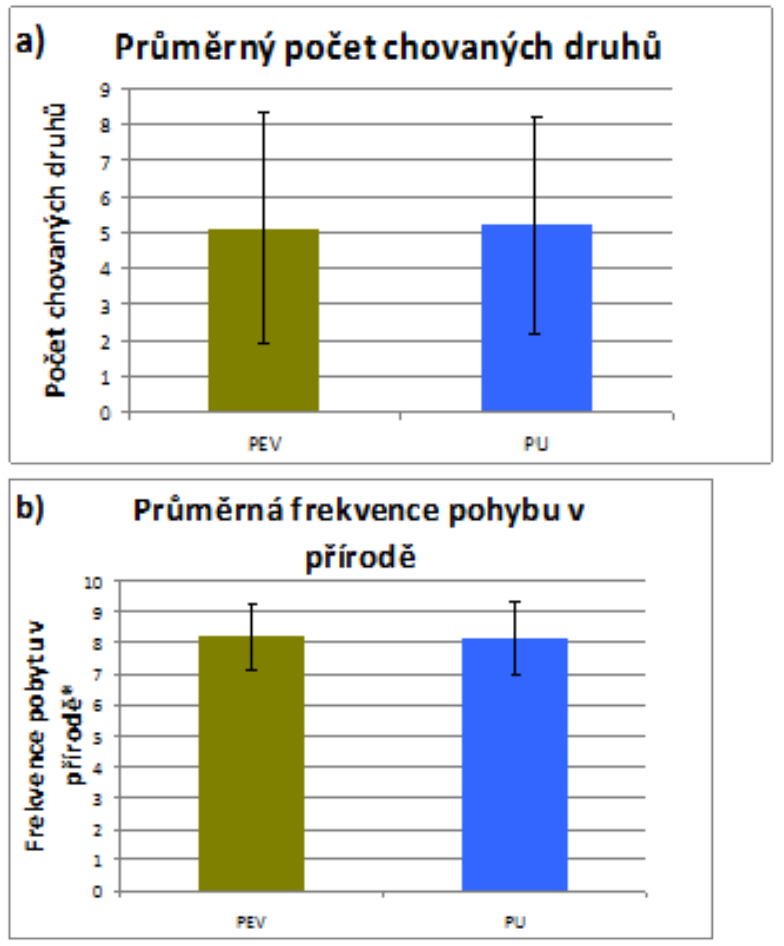


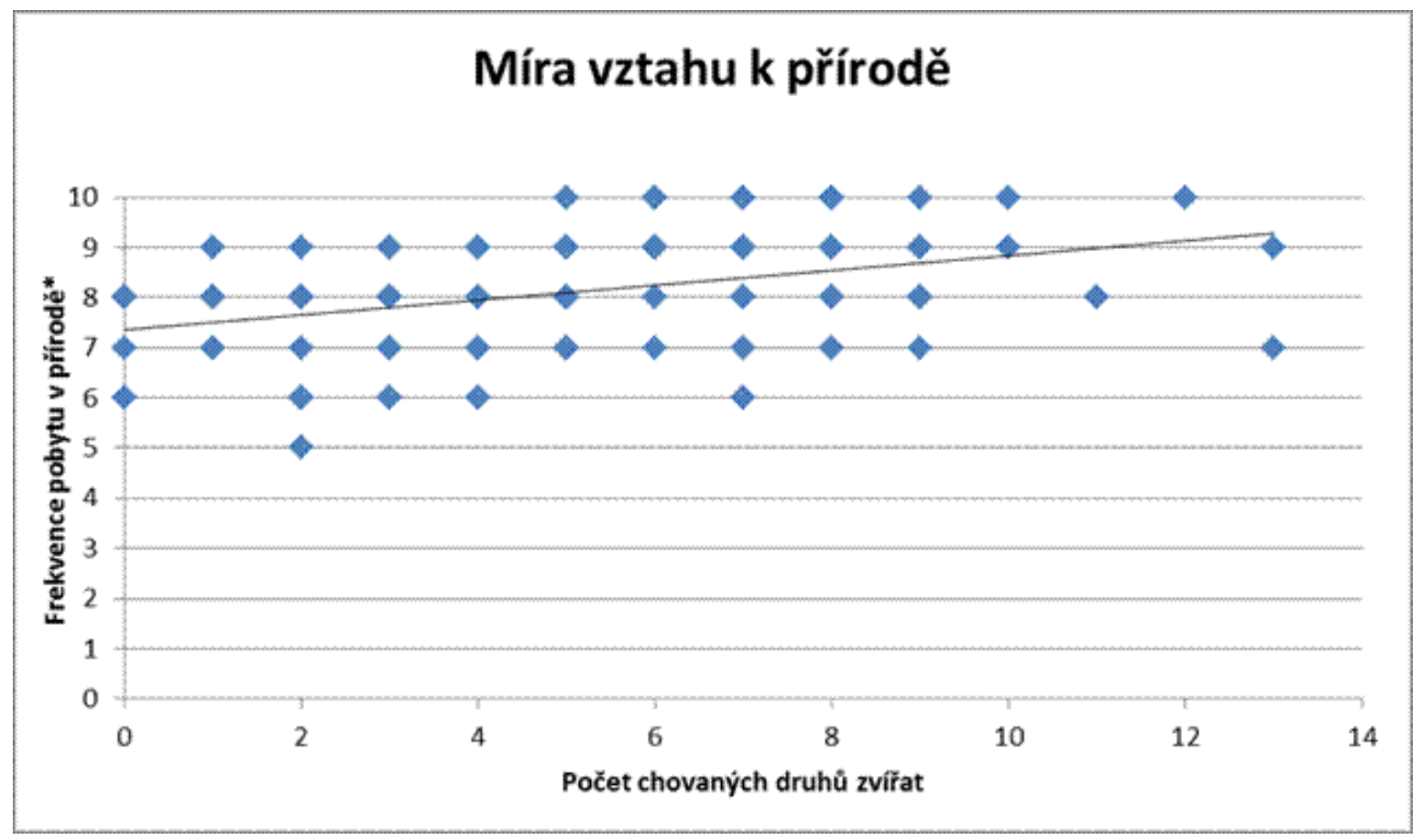

Obr. 2. Výsledky sledování míry vztahu k přírodě zobrazující

a) počty chovaných druhů zvíratat na studenta,

b) čas strávený ve volné přírodě a

c) závislost mezi počtem druhů chovaných zviŕat $(x)$ a množstvím času stráveného $v$ prírodě $(y)$. Obě veličiny jsou závislé podle funkce $y=0,39 x+7,37 ; R=0,392$. (* hodnoty na ose y odpovídají 10-bodové škále frekvence návštěv a vycházek do prírody: 10 bodů - několikrát denně, 9 bodů - každý den, 8 bodů - několikrát týdně, 7 bodů - jednou týdně, 6 bodů - několikrát měsíčně, 5 bodů - jednou měsíčně, 4 body - několikrát do roka, 3 body - jednou za rok, 2 body - několikrát v životě, 1 bod - nikdy).

\section{(c) Proenvironmentální chování}

Studenti obou oborů (PEV i PU) vykazují podobnou míru proenvironmentálního chování (obr. 3a) a mezi oběma skupinami nebyly zjištěny statisticky významné rozdíly. Součtem bodů získaných ve všech pěti dotazovaných aktivitách dosáhli studenti PEV průměrně 26 bodů, studenti PU 24 bodů. Nejaktivnější byli studenti 1 . ročníku PEV ( $v$ průměru dosahovali součtu 28 bodů) a 3. ročníku PEV (27 bodů). Nejméně bodů (23) dosáhli studenti 3. ročníku PU. z detailních výsledků vyplývá, že vyšší míru aktivity hlásili studenti PEV ve třídění odpadů, koupi BIO výrobků a českých výrobků a v účasti na akcích; nepatrně nižší míru v koupi EKO výrobků. 

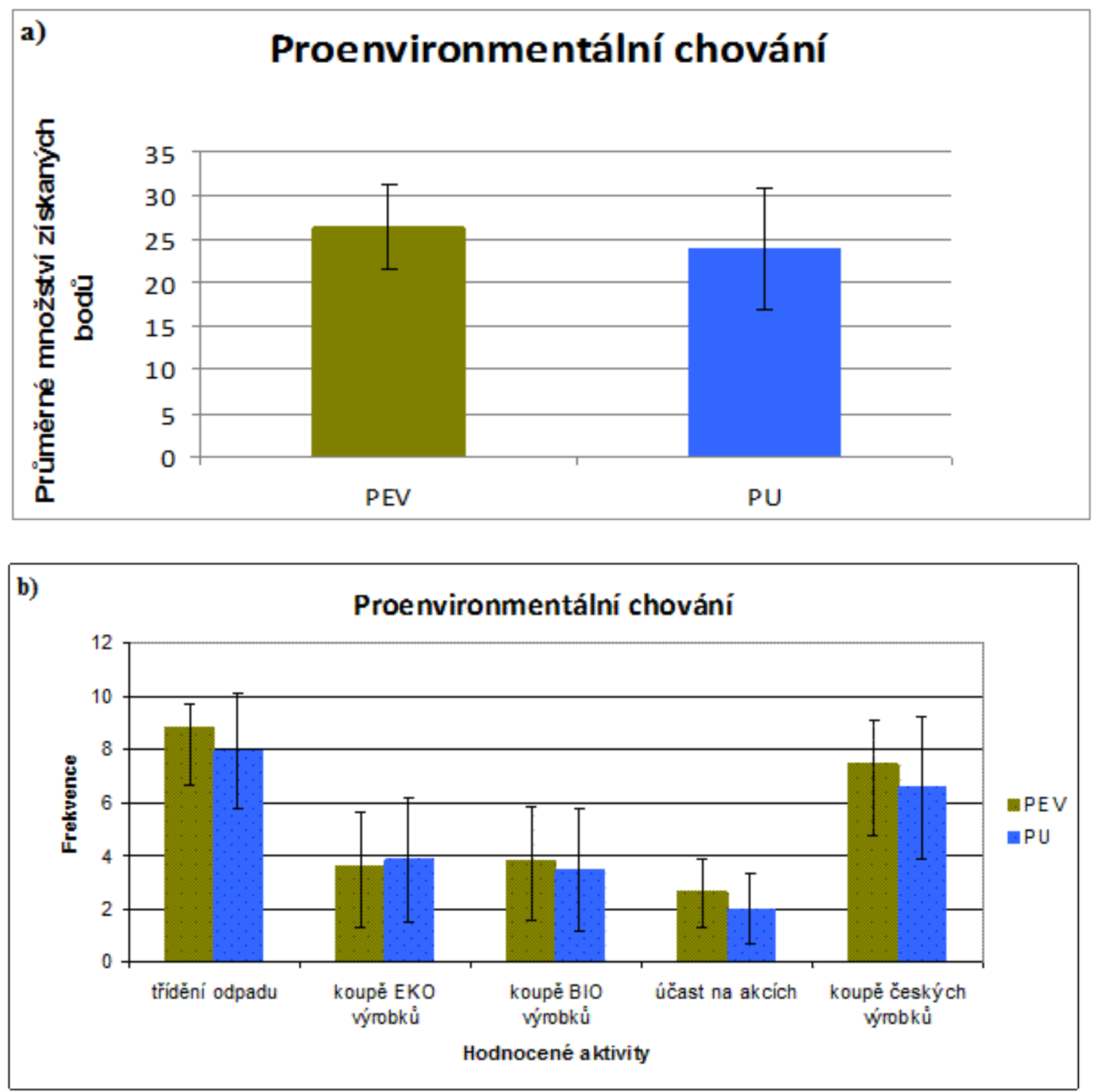

Obr. 3. Porovnání míry proenvironmentálního chování studentů PU a PEV. Osa y na obr. 3a uvádí průměrné množství bodů získaných pro daný obor. Na obr. 3b uvádí osa y průměrnou frekvenci aktivit. Pro hodnocení frekvence chování byla použita desetibodová škála: 10 bodů - několikrát denně, 9 bodů - jednou denně, 8 bodů několikrát týdně, 7 bodů - jednou týdně, 6 bodů - několikrát měsíčně, 5 bodů - jednou měsičně, 4 body - několikrát ročně, 3 body - jednou ročně, 2 body - několikrát za život, 1 bod - nikdy.

\section{(d) Zákonitosti}

Výsledky průzkumu prokázaly, že studenti obou sledovaných skupin, tedy PU i PEV (obr. 4) přicházejí do 1 . ročníku se srovnatelným stupněm znalostí vztahů mezi rostlinami a atmosférou. Rozdíly mezi sledovanými obory zjištované Studentovým t - testem nebyly statisticky významné. Uváděny byly pouze dva vztahy, a to obohacování atmosféry o kyslík a fixace oxidu uhličitého rostlinami z atmosféry - tedy oba dva vztahy související pouze s fotosyntézou. Ani ve druhém ročníku nelze pozorovat statisticky významné rozdíly mezi oběma studijními obory. Došlo však u obou sledovaných skupin k nárüstu 
průměrného počtu vztahů a to ve srovnatelné míře u obou studijních oborů. Rozdíly mezi prvním a druhým ročníkem jsou u obou sledovaných oborů statisticky významné ( $t$ - test, $a=0,05)$. Statisticky významný rozdíl mezi výsledky studentů PU a PEV byl poprvé pozorován až ve třetím ročníku.

Stejně tak $v$ oblasti studia neživé př́rody nebyly shledány statisticky významné rozdíly mezi studenty PEV a PU $v$ prvním ani ve druhém ročníku. i v tomto prípadě byl statisticky významný rozdíl zaznamenán až ve třetím ročníku, kdy u studentů PEV došlo $\mathrm{k}$ poklesu prüměrného počtu uváděných příčin eroze.

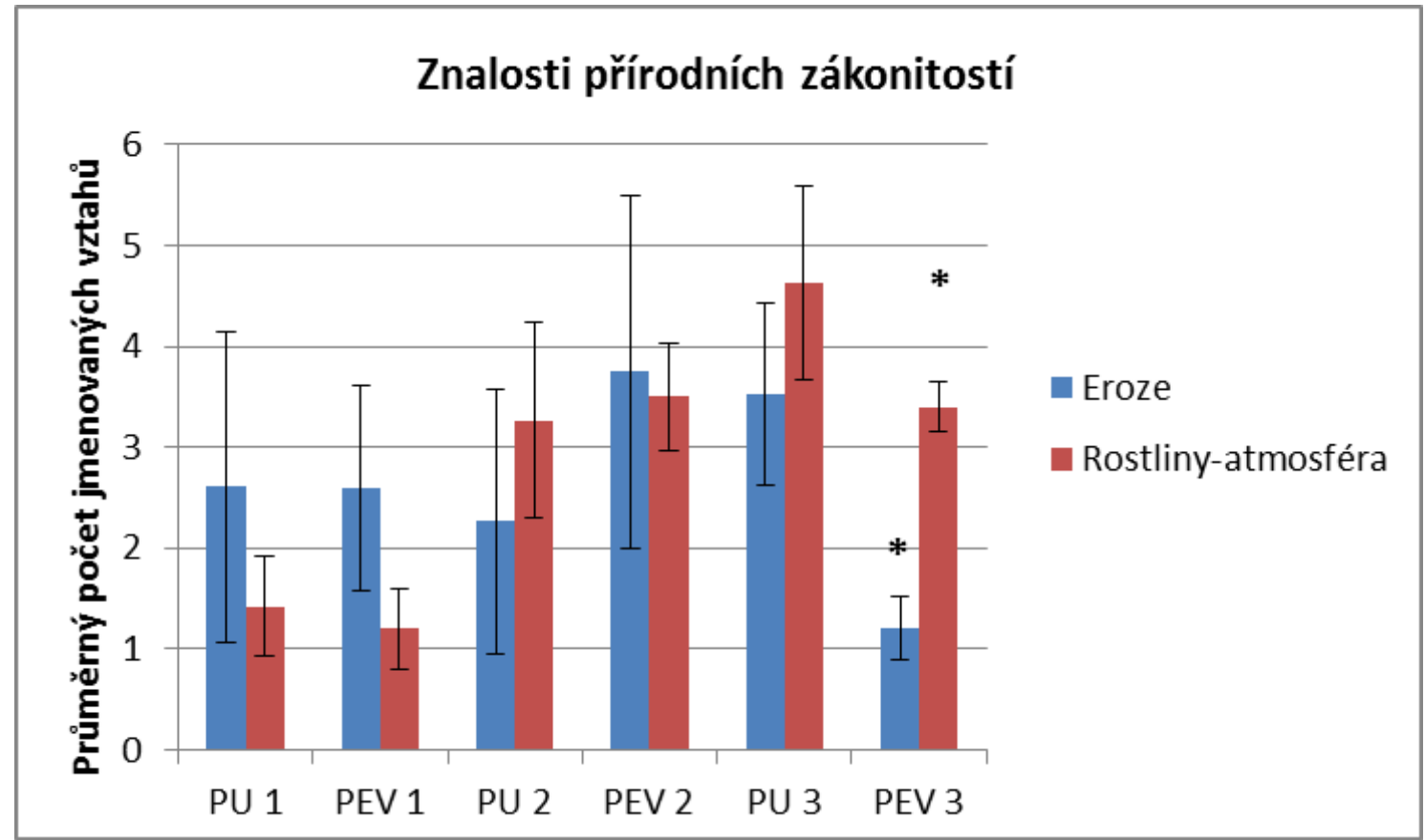

Obr. 4. Znalost přírodních zákonitostí. Osa y uvádí průměrné počty správně uvedených vztahů mezi rostlinou a atmosférou resp. erozí a antropogenní činností. * = statisticky významný rozdíl mezi sledovanými skupinami PEV a PU (Studentův t- test a $=$ $0,05)$.

Překvapivě malé procento (3\%) správných odpovědí vysvětlujících pojem „Trvale udržitelný rozvoj" bylo zaznamenáno u studentů 1 . ročníku oboru PU. Naopak studenti oboru PEV začínají v prvním ročníku studium s podstatně lepší mírou informovanosti $\checkmark$ oblasti trvale udržitelného rozvoje, většina $(60 \%)$ odpověděla správně. s postupující dobou studia na katedře biologie PF JU se informovanost studentů o trvale udržitelném rozvoji zvyšuje, zatímco u studentů PEV zůstává na přibližně stejné, tj. vysoké úrovni jako v prvním ročníku (obr. 5). Rozdíly mezi oběma skupinami respondentů však zůstávají statisticky významné po celou dobu studia. 


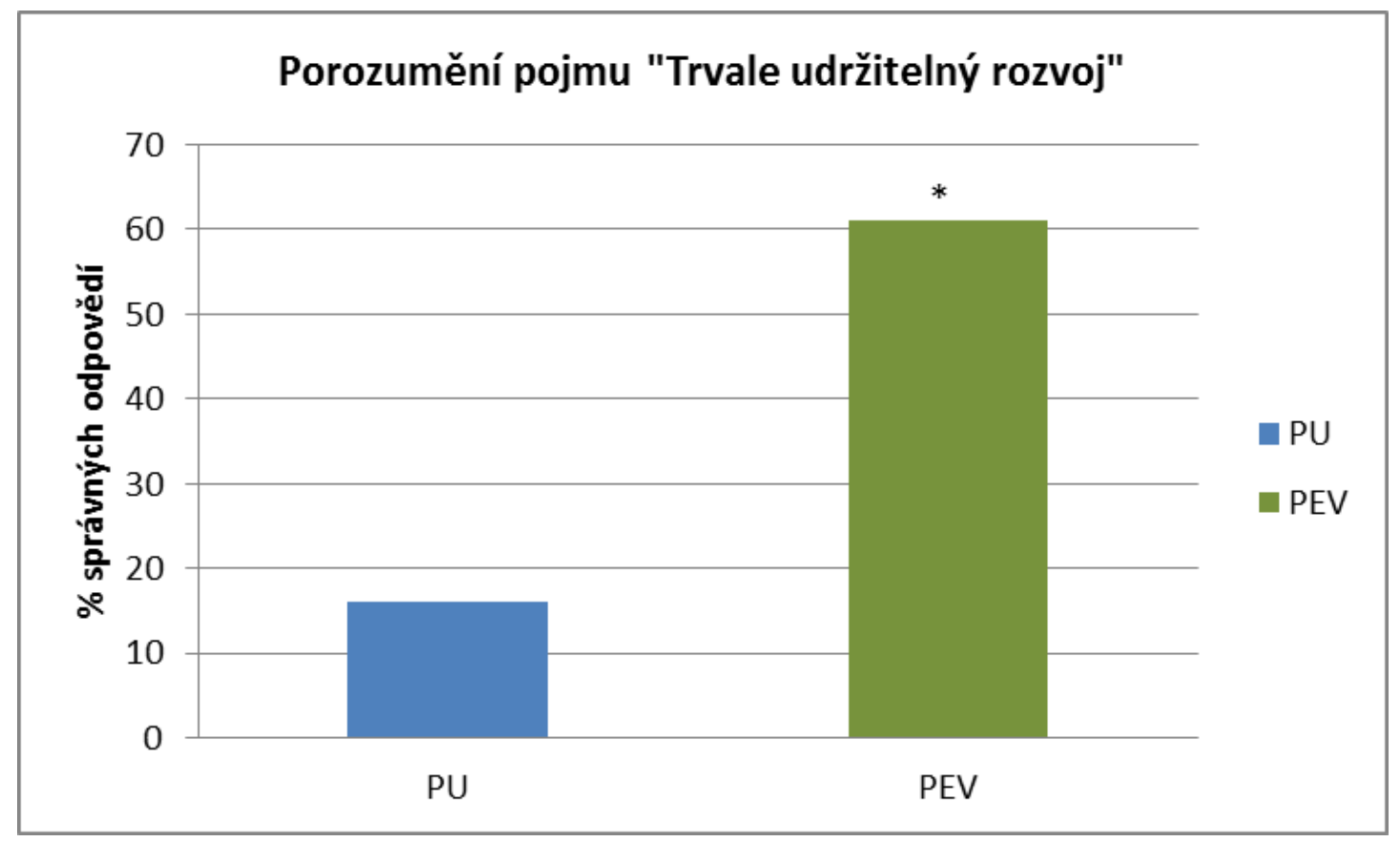

Obr. 5. Vysvětlení pojmu „Trvale udržitelný rozvoj”. Údaje uvádějí procentuální zastoupení studentů $v$ jednotlivých testovaných skupinách, kteří odpověděli správně, * = statisticky významný rozdíl mezi sledovanými skupinami (Studentův t- test a $=0,05$ ).

\section{(e) Výzkumné dovednosti}

Dle očekávání největší chybovost $v$ seřazování etap pokusu byla u studentů 1 . ročníku obou sledovaných oborů bez statisticky významného rozdílu mezi obory (obr. 6). Nejmenší chybovost byla zaznamenána u studentů třetího ročníku obou sledovaných oborů. Podle výsledků statistické analýzy za použití studentova t-testu nebyly shledány statisticky významné rozdíly mezi studenty prvního a druhého ročníku ani u jedné z obou sledovaných skupin. Ve třetím ročníku však již došlo ke statisticky významnému nárůstu správných odpovědí u obou sledovaných skupin a zároveň i k významnému rozdílu mezi 3. ročníkem PEV a 3. ročníkem PU. 


\section{Seřazení etap průběhu pokusu}

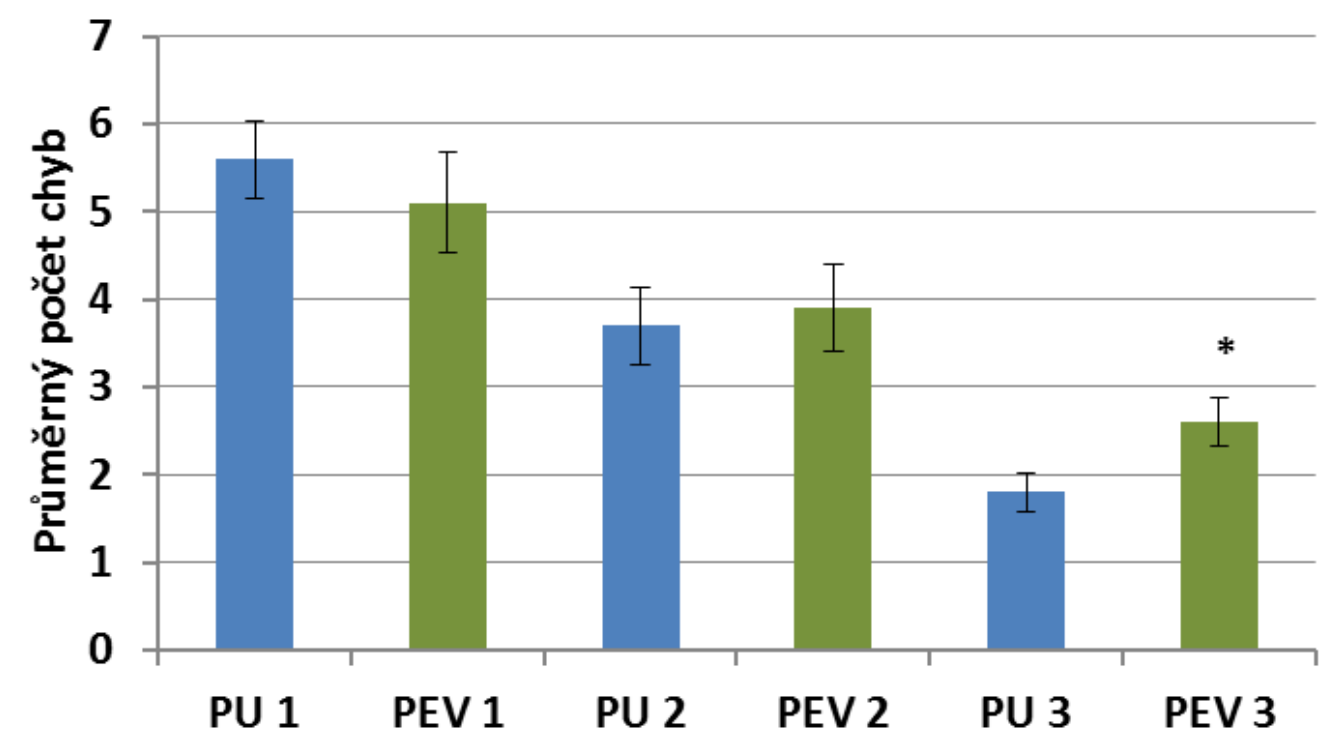

Obr. 6. Průměrný počet chyb $v$ testování výzkumných dovedností ( $\pm \mathrm{sm}$. odchylka), * = statisticky významný rozdíl mezi studenty skupiny PEV a PU téhož ročníku (Studentův $\mathrm{t}$ - test, $\mathrm{a}=0,05$ )

\section{Diskuse}

\section{(a) Absolvovaný typ střední školy ve vztahu k výsledkům sondy}

Z výsledků vyplývá, že v některých kategoriích (proenvironmentální chování, znalost pojmu trvale udržitelného rozvoje) si studenti 1 . ročníku PEV vedli lépe v porovnání se studenty PU. Zaměření témat, ve kterých jednotlivé obory dosahují lepších výsledků, koresponduje s většinovým zaměřením středních škol, ze kterých se studenti na obory hlásí. Proto Ize spekulovat, že ekologicky, či zemědělsky orientované SŠ mohou dávat studentům PEV silnější základ $v$ environmentálně laděných tématech a vedou je více k proenvironmentálnímu chování, než gymnázia, z nichž přichází převážná většina studentů PU. Podle výsledků některých výzkumů (např. Barraza, 1999; Korhonen, 2004) Ize usuzovat, že absolvovaný typ středoškolského vzdělání bude mít větší vliv na odpovědi studentů 1. ročníků, obzvláště $v$ prípadě testování na začátku akademického roku, $a$ $s$ délkou studia by se měl vliv absolvovaného typu SŠ zmenšovat. $v$ tomto směru tedy výsledky sondy přinášejí podnět pro budoucí výzkumná šetření.

\section{(b) Vztah k přírodě}

Mezi sledovanými studijními skupinami PU a PEV nebyly zjištěny statisticky významné rozdíly ani v počtu chovaných zviŕat, ani v délce času stráveného v přírodě.

Při interpretaci zjištěných závěrů je však nutno mít na zřeteli, že množství a druhy chovaných zviŕat nemusí vždy odrážet pouze vztah ke zviŕatům. Na počet chovaných zviŕat mohou mít vliv i další faktory, jako např́íklad rodinné zázemí, ekonomické či sociální podmínky. Velké množství testovaných studentů pochází z rurálních oblastí, poprípadě z rodinných farem, kde je větší důraz kladen na pěstování užitkových zviŕat a práci s nimi. Tento trend životního stylu je typický pro jihočeské regiony a bylo by zajímavé srovnat výsledky podobných analýz provedených i v ostatních regionech republiky. 
Problematické se také ukázalo být chápání pojmu "čas trávený v přírodě". Například denní cesta do školy / práce není považována za plnohodnotný a aktivní pobyt v přírodě, který by mohl být započítáván. Naopak venčení psa je přijatelný př́klad. Pro přesnější hodnocení by bylo potřeba tuto otázku více rozvinout a dát studentům možnost se vyjádřit k tomu, jaký způsob pobytu mají na mysli. Je také spousta př́padů, u kterých je kvalita pobytu v prrírodě sporná (výlety autem, sportovně laděné pobyty jako jogging se sluchátky na uších, dlouhé cyklovýlety, atd).

\section{(c) Proenvironmentální chování}

Celkově z výsledků sondy vyplývá přibližně shodná úroveň proenvironmentálního chování u obou sledovaných studijních skupin.

Úroveň proenvironmentálního chování může souviset s kurikulem oborů. Dá se tak například vysvětlit nižší úroveň zjištěná u 3. ročníku PU, které je v bakalářském studiu zaměřeno více na znalosti oborových témat než na vedení kaktivnímu proenvironmentálnímu jednání.

Hodnocené aktivity zahrnuté do kategorie proenvironmentálnícho chování mohou ale odrážet i některé další intervenující faktory, jako například místo pobytu studenta během studia (doma s rodiči, na koleji, v podnájmu), kde třídění odpadu odráží chování celé skupiny, nikoliv pouze testovaného jedince. Vyšší cena EKO a BIO výrobků, na jejichž koupi se test soustřed'uje, zase s největší pravděpodobností odráží ekonomickou situaci studenta (respektive rodičů). Studenti poměrně často zmiňovali upřednostňování českých výrobků před zahraničními, i přes to, že v mnohých př́padech jsou zahraniční výrobky levnější. To může indikovat pozitivní uvědomění si environmentálních faktorů, které jsou spjaté s globálním trhem (např. dlouhé transporty). Velmi nízká účast studentů na environmentálních akcích mưže být ovlivněna nízkým počtem příležitostí, nebo jejich medializací, který se může lišit v závislosti na regionech. Vliv zmíněných faktorů na hodnocené aktivity by tedy jistě vyžadoval další průzkum.

\section{(d) Zákonitosti}

Úroveň znalostí přírodních zákonitostí je u obou prvních ročníků stejná, což mưže být způsobeno velkým množstvím společných přednášek. Ve druhém ročníku dochází k nárůstu znalostí vztahů zejména u studentů PEV, zřejmě pod vlivem specifických přednášek, které absolvují studenti PEV během druhého ročníku (pedologie, klimatologie, hydrologie, pěstitelství, zahradnictví, globální problémy životního prostředí). Ve třetím ročníku jsou si více vědomi vztahů a principů životního prostředí studenti PU než studenti PEV. Hlavní příčina tohoto vývoje je spatřována v odlišnostech kurikula obou oborů. Zatímco výuka 3. ročníku PEV je už zaměřena spíše na praktické aspekty budoucí praxe (tzn. pedagogicko-psychologické a didaktické předměty), výuka PU pokračuje i ve 3. ročníku v prohlubování biologicky zaměřených předmětů rozvíjející jejich znalosti př́rodních zákonitostí, (např. povinný kurz základů pedologie, hydrologie a klimatologie), a didaktické a pedagogicko-psychologické předměty jsou zařazeny až do navazujícího magisterského studia.

Konkrétně, v oblasti vztahů mezi rostlinami a atmosférou nebyly zaznamenány statisticky významné rozdíly mezi sledovanými skupinami u studentů prvního ročníku. Ve druhém ročníku došlo $\mathrm{k}$ významnému nárůstu znalostí vztahů mezi rostlinami a atmosférou u obou sledovaných skupin respondentů. Tento nárůst byl zřejmě způsoben výukou předmětu Fyziologie rostlin u studentů druhého ročníku PU a předmětu Pedologie, klimatologie a hydrologie u studentů 2. ročníku PEV. Zatímco v prvním ročníku byla znalost vztahů mezi rostlinami a atmosférou omezena pouze na děje související prímo s fotosyntézou, ve druhém ročníku byly již uváděny i oboustranné vztahy mezi rostlinami a atmosférou zahrnující procesy transpirace - tedy ochlazování mikroklimatu stanoviště rostlinami i vliv vzdušné vlhkosti na rostliny, dále také rostlinné emise těkavých organických látek, výjimečně se vyskytl i vliv rostlin na odstranění prachových částic z ovzduší. Zajímavý je ale vývoj ve třetím ročníku, kde sice ani u jedné skupiny nedošlo 
k nárůstu počtu uváděných vztahů, u skupiny PU ale vzrostl počet studentů uvádějících více vztahů, což přispělo k statisticky významnému rozdílu mezi výsledky sledovaných studijních oborů.

U skupiny PEV k dalšímu rozvoji ve třetím ročníku ve srovnání s druhým již nedošlo. i tento trend koreluje $\mathrm{s}$ obsahem výuky. U studentů $\mathrm{PU}$ je zařazen ve třetím ročníku předmět Pedologie, klimatologie a hydrologie, který studenti PEV absolvují již ve druhém ročníku. Celkově studenti PU mohli tedy pro zodpovězení otázky č. 5 využít své znalosti z předmětu Fyziologie rostlin z druhého ročníku a Pedologie, klimatologie a hydrologie ze třetího ročníku. Naproti tomu studenti PEV předmět Fyziologie rostlin neabsolvují během svého studia vůbec. v okamžiku absolutoria bakalářského studia vykazují tedy studenti oboru PU průměrně vyšší množství znalostí zákonitých vztahů mezi rostlinami a atmosférou než studenti PEV.

Studenti prvních ročníků PEV i PU téměř shodně jmenovali v průměru na osobu tři správné přičiny urychlení eroze (viz. obr. 4). Nejčastěji byla zmiňována stavební činnost, obnažení hornin za účelem tě̌̌by či skrývky a odlesňování. Za další př́činy, i když méně často jmenované, byly $v$ obou ročnících považovány znečištění životního prostředí, přejezdy těžkou technikou, vrty, provádění terénních úprav a zakládání skládek. Našli se však i dva studenti 1 . ročníku PU, kteří byli toho názoru, že člověk nijak neurychluje erozi hornin. Ve druhém ročníku se projevily mírné rozdíly. Zatímco studenti PEV jmenovali $v$ průměru 4 př́činy, studenti PU pouze dvě. u studentů druhého ročníku PEV došlo oproti prvnímu ročníku téhož oboru $\mathrm{k}$ statisticky významnému nárůstu průměrného počtu odpovědí. Rozdíly mezi studijními skupinami PEV a PU však nebyly ani ve druhém ročníku vzhledem $k$ velkému rozptylu $v$ počtu odpovědí statisticky významné. $v$ obou prípadech bylo nejčastěji uváděno odlesňování a obnažování hornin za účelem těžby nebo skrývky. Tři studenti uvedli, že člověk nijak neurychluje erozi. Statisticky významné rozdíly mezi sledovanými studijními skupinami se objevily až ve třetím ročníku. Zatímco studenti 3. ročníku PU uváděli $v$ průměru 4 odpovědi na osobu, studenti PEV pouze jednu (většinou odlesňování), jeden student PEV uvedl, že člověk neurychluje erozi vůbec. Ve 3. ročníku PU uvedlo několik studentů ( 4 z 19) jako prríčinu urychlení eroze výsadbu stromů, respektive biologické zvětrávání způsobené kořenovým dýcháním. Tato odpověd' poukazuje na hlubší uvažování $v$ rámci vztahů mezi živou a neživou prírodou vycházející pravděpodobně z obsahu přednášek Fyziologie rostlin (2. ročník) a Pedologie, klimatologie a hydrologie (3. ročník), nelze ji ovšem považovat za jasný příklad př́činy urychlení eroze.

Studenti PEV ale na rozdíl od studentů PU lépe chápou pojem trvale udržitelný rozvoj, Ize tedy předpokládat, že dosažené znalosti zákonitostí budou schopni interpretovat ve smyslu trvale udržitelného rozvoje. Míra správného pochopení pojmu Trvale udržitelný rozvoj může být $v$ tomto př́ipadě ovlivněna zřejmě opět absolvovaným typem střední školy. Studenti PU si bohužel ze střední školy nepřinášejí téměř žádné informace o trvale udržitelném rozvoji. Většina z nich se domnívá, že se jedná o neustále se zrychlující vědeckotechnický rozvoj, ekologická část tohoto pojmu jim však bohužel vůbec není známa. s postupující délkou studia se ale stupeň pochopení správného smyslu i u studentů PU zvyšuje (viz obr.5).

\section{(e) Výzkumné dovednosti}

Sonda prokázala pozitivní vliv vzdělávacího procesu a zároveň i uplatňování principu BOV ve sledované oblasti Výzkumné dovednosti.

Jak vyplývá z obr. č. 6 , schopnost studentů sestavit ve správném pořadí etapy pokusu se zlepšuje $v$ souladu s délkou studia. Největší chybovost byla zjištěna u studentů prvního ročníku. Ve druhém a třetím ročníku chybovost postupně u obou sledovaných skupin klesá. Navíc ve třetím ročníku byl také zjištěn statisticky významný rozdíl mezi skupinami PU a PEV ve prospěch PU. k výraznému nárůstu výzkumných dovedností ve 3. ročníku PU zřejmě přispěl fakt, že $v$ tomto ročníku je $v$ oboru PU větší počet studentů, kteří řeší bakalářskou práci s tematikou BOV a problematiku etap experimentu tedy dobře znají. Zároveň studenti oboru PU na rozdíl od oboru PEV absolvovali kurzy, které více čerpají 
z výzkumných činností, a kde je princip BOV uplatňován $v$ řadě tematických celků (např́klad Fyziologie rostlin, Zoologie obratlovců, atd.).

\section{Závěr}

Provedená pilotní sonda testovala environmentální gramotnost studentů dvou prírodovědně zaměřených oborů $\mathrm{s}$ cílem zjištění a porovnání výsledků absolventů a prvotního ověření možnosti vytvoření komplexního nástroje pro měření environmentální gramotnosti ve vztahu s některými klíčovými tématy DOV.

Výzkum potvrdil, že studenti obou bakalářských oborů mají srovnatelnou úroveň environmentální gramotnosti. Zjištěné rozdíly v oblastech "Zákonitosti" a "Výzkumné dovednosti" mezi studenty PEV a PU odrážejí odlišnosti kurikula a akcenty studia jednotlivých oborů, výstupy však odpovídají zaměření budoucí praxe absolventů (výuka oboru PEV je již během bakalářského studia zaměřena stejnou měrou na praktické aspekty budoucí praxe (tzn. pedagogicko-psychologické a didaktické předměty) jako na znalosti př́rodních zákonitostí; výuka strukturovaného bakalářského oboru PU plně spočivá v prohlubování kognitivní báze biologicky zaměřených témat, protože didaktické a pedagogicko-psychologické předměty jsou zařazeny až do navazujícího magisterského studia. Absolventi bakalářského studia PEV jsou $v$ době ukončení 3. ročníku připraveni působit $v$ oblasti mimoškolní environmentální výchovy a jejich předpokládané pưsobení bude spíš výchovného, motivačního a informativního charakteru. Na druhé straně absolventi bakalářského studia oboru PU mají silný kognitivní základ pro další pokračování v navazujícím magisterském studiu a následném působení ve školním vzdělávání př́rodopisu a biologie. Př́nos badatelsky orientovaného vyučování, se kterým se studenti na katedře biologie PF JU během svého studia setkávají jak v rámci výuky jednotlivých disciplin, tak i při řešení svých bakalářských prací Ize spatřovat především $\mathrm{v}$ oblasti výzkumných dovedností. Vliv této moderní metody výuky na další oblasti environmentální gramotnosti vyžaduje hlubší průzkum a především vytvoření standardní a všeobecně akceptovatelné metodiky hodnocení environmentální gramotnosti, jejíž absence je v oblasti české environmentální výchovy velmi citelná.

Kromě kurikula a akcentu studia může mít menší vliv na rozdílné výsledky především prvních ročníků i typ absolvovaných středních škol, ze kterých se studenti na jednotlivé obory hlásí. Zatímco většina studentů PU je absolventy gymnázií, v oboru PEV absolvovalo gymnázium jen málo studentů. Absolvovaný typ střední školy pak může v konečném důsledku mít vliv napřs. na větší informovanost o environmentálních pojmech a tématech. u vyšších ročníků se však vliv SŠ už nepředpokládá.

Pilotní sonda ukázala, že některé indikátory environmentálních kompetencí použité $v$ testu je potřeba rozširíit a umožnit tak sledovat vliv intervenujících pozad'ových proměnných. Bylo by zajímavé sledovat například korelaci demografických a socioekonomickcých dat s environmentální citlivostí a akční strategií respondentů. Některé indikátory by mohly být doplněny o detailnější vyjádření $\mathrm{k}$ jednotlivým odpovědím (napríklad jaké způsoby pobytu $v$ prírodě mají respondenti na mysli, jaké konkrétní výrobky upřednostňují, či jakých konkrétních akcí se zúčastnili). Odpovědi tohoto typu by však musely být získávány formou řízeného rozhovoru (s doplňujícím kvalitativním průzkumem). Více prostoru by mohlo být věnováno i testování znalostí mezioborového přesahu (např́klad vztahy mezi chemickými, geografickými, biologickými, ale i ekonomickými a sociologickými jevy). Prokazatelný vliv absolvované SŠ a kurikula i akcentu studia na environmentální gramotnost by byl doložitelný až dlouhodobým testováním studentů $v$ průběhu studia (na začátku 1. ročníku, na konci 2 . ročníku a na konci 3. ročníku).

Indikátory navržené v předložené sondě nezahrnují klíčové téma „DOV „Problémy a konflikty" Vzhledem k vymezení obsahu tohoto tématu je pro vytvoření jednoznačného 
indikátoru zapotřebí samostatné studie. Pro posouzení tohoto tématu by zřejmě bylo vhodné uvažovat o využití metody kvalitativního výzkumu.

Ověření reliability navržených indikátorů samozřejmě vyžaduje testování na rozsáhlejších souborech respondentů. Tato pilotní sonda však byla koncipována jako pretest, s cílem inspirovat ke vzniku nástroje pro hodnocení environmentální gramotnosti $v$ českém prostředí.

\section{Literatura:}

- BARRAZA, I, (1999). Children's drawings about environment. Environmental education research. Environmental education research, 1, 18-49.

- Bowler, D., BUYUNG-ALI I,, Knight, T., \& Pulli, A. (2010). Urban greening to cool towns and cities: A systematic review of the empirical evidence.Landscape and urban planning, 97, 147155.

- Činčera, J. (2011). Doporučené očekávané výstupy pro environmentální výchovu. Envigogika, 6(2), Retrieved from http://www.envigogika.cuni.cz/index.php/cz/recenzovane-clanky/2011/envigogika2011vi2/581-doporucene-ocekavane-vystupy-pro-environmentalni-vychovu

- Činčera, Efektivity environmentální výchovy. In S. Vincíková (Ed.), Environmental Management for Education and Edification 1 (1) (pp. 95-103). Bánská Bystrica: Univerzita Mateja Béla.

- Činčera, J., \& Štěpánek, P. (2007). Výzkum ekologické gramotnosti studentů středních odborných Škol. Envigogika, 2(1), Retrieved from http://www.envigogika.cuni.cz/index.php/Envigogika/article/viewFile/12/pdf 12

- Komise, E. (2007). Science Education NOW. . Retrieved from http://ec.europa.eu/research/science-society/document library/pdf 06/report-rocard-onscience-education en.pdf

- Forbes, C. T., Cory, T., \& Zint, M. (2011). Elementary teacher's beliefs about, perceived competencies for, and reported use of scientific inquiry to promote student learning about and for the environment. Journal of Environmental Education, 42(1), 30-42. Retrieved from http://www.tandfonline.com/doi/abs/10.1080/00958961003674673 http://dx.doi.org/10.1080/00958961003674673

- Fowler, D. (2009). a kol. Atmospheric composition change: Ecosystems - Atmosphere interactions. Atmospheric Environment, 43(33), 5793-5267.

- Franěk, M. (2012). Nature Relatedness Scale. Český překlad škály měřící spojení s prírodou. Envigogika, 7(1), Retrieved from http://www.envigogika.cuni.cz/index.php/cz/recenzovane-clanky/2012/envigogika-2012-vii1/660-nature-relatedness-scale-cesky-preklad-skaly-merici-spojeni-s-prirodou

- GEUNTHER, A. B., HEWIT, C. N., ERICKSON, D., FALL, R., GERON, C., GRAEDEL, T., HARLEY, P., KLINGER, L., LERDAU, M., MCKAY, W.A., PIERCE, T., SCHOLES, B., STEINBRECHER, R., TALLAMRAJU, R., TAYLOR J .\& ZIMMERMAN, P., (1995). A global model of natural volatile organic compound emission. Journal of Geophysical Research, 100, 8873-8892.

- Hsu, S. J. (2004). The effects of an environmental education program on responsible environmental behaviour and associated environmental literacy variable in Tawanese college students. Journal of Environmental Education, 35(2), 37-48. Retrieved from http://www.tandfonline.com/doi/abs/10.3200/JOEE.35.2.37-48 http://dx.doi.org/10.3200/JOEE.35.2.37-48 
- Chawla, L. (1999). Life Paths Into Effective Environmental Action. The Journal of Environmental Education, 31(1), 15-26. Retrieved from http://www.tandfonline.com/doi/abs/10.1080/00958969909598628 http://dx.doi.org/10.1080/00958969909598628

- Cheng, J. C., \& Monroe, M. C. (2010). Examining Teachers' Attitudes Toward a Required Environmental Education Program. Applied Environmental Education \& Communication, 9(1), 28-37. Retrieved from http://www.tandfonline.com/doi/abs/10.1080/15330150903566463 http://dx.doi.org/10.1080/15330150903566463

- Jančaříková, K. (2009). Zooasistence v pedagogické praxi. Envigogika [online]. Envigogika, 4(3), Retrieved from http://www.envigogika.cuni.cz/index.php/cz/cs/texty/20093/340-zooasistence-vpedagogicke-praxi

- Korhonen, K., \& Lappalainen, A. (2004). Examining the environmental awarness of children and adolescents in the Ranomafana region, Madagaskar.Environmental Education Research, 10(2), 195-216. Retrieved from http://www.tandfonline.com/doi/abs/10.1080/13504620242000198177 http://dx.doi.org/10.1080/13504620242000198177

- Kravcik, M., Pokorny, J., Kohutiar, J., Kovac, M., \& Water, T. E. (2008). Water for the Recovery of the Climate - A New water Paradigm. . Retrieved from http://waterparadigm.org/

- Lubezki, A., Dori, J., \& Zoller, U. (2004). HOCS-Promoting Assessment of Students Performance on Environment Related Undergraduate Chemistry. Chem. Educ. Res. Pract, 5(2), 175-184.

- McMillan, E. E., Wright, T., \& Beazley, K. (2004). Impact of a University-Level Environmental Studies Class on Students' Values. The Journal of Environmental Education, 35(3), 19-27. Retrieved from http://www.tandfonline.com/doi/abs/10.3200/JOEE.35.3.19-27 http://dx.doi.org/10.3200/JOEE.35.3.19-27

- MICHAELS, S., Shouse, A. W. \& Schweingruber, H. A., (2008). Ready, Set, Science! Putting research to work in $\mathrm{K}-8$ science classrooms. Washington D.C.: National Research Council. National Academic Press. Retrieved from http://www.nap.edu/catalog.php?record id=11882

- Osborne, J., Dillon, J., (2008). Science Education in Europe: Critical Reflections. . Retrieved from http://www.nuffieldfoundation.org/fileLibrary/pdf/Sci Ed in Europe Report Final.pdf

- Papáček, M. Limity a šance zavádění badatelsky orientovaného vyučování přírodopisu a biologie $v$ České republice. In Papáček, M. (Ed.) (Ed.), Didaktika biologie $v$ České republice 2010 a badatelsky orientované vyučování. DiBi 2010. Sborník př́spěvků semináře, 25. a 26. března 2010 (pp. 145-162). České Budějovice: Jihočeská univerzita.

- Pastorová, M. a kol, (2011). Doporučené očekávané výstupy. Metodická podpora pro výuku prưrezových témat na základních školách. Praha: Výzkumný ústav pedagogický. Retrieved from http://www.vuppraha.cz/nova-publikace-divize-vup-\%E2\%80\%93-doporuceneocekavane-vystupy-pro-zakladni-skoly

- Pastorová, M. a kol, (2011). Doporučené očekávané výstupy. Metodická podpora pro výuku prưrezových témat $v$ gymnáziích. Praha: Výzkumný ústav pedagogický. Retrieved from http://www.vuppraha.cz/wp-content/uploads/2011/10/Doporucene ocekavane -vystupy gymnazia.pdf

- Pokorny, J. Brom, J., Cermak, J., Hesslerova, P., Huryna, H., Nadezsina, N., Rejskova, A, (2010). Solar energy dissipation and temperature control by water and plants. Int. Journal of Water, 5, 311-336. 
- Ryplová, R., \& Reháková, J. (2011). Prínos badatelsky orientovaného vyučování (BOV) pro environmentální výchovu: Prípadová studie implementace BOV do výuky na ZŚ. s. C15. Envigogika, 6(3), Retrieved from http://www.envigogika.cuni.cz/index.php/cz/recenzovane-clanky/2011/envigogika2011vi3/606-prinos-badatelsky-orientovaneho-vyucovani-bov-pro-environmentalni-vychovupripadova-studie-implementace-bov-do-vyukyna-zs

- Sivek, D. J. (2002). Environmental Sensitivity among Wisconsin High School Students. Environmental Education Research, 8(2), 155-170. Retrieved from http://www.tandfonline.com/doi/abs/10.1080/13504620220128220 http://dx.doi.org/10.1080/13504620220128220

- Smiatek, G., \& Steinbrecher, R. (2006). Temporal and spatial variation of forest VOC emissions in Germany in the decade 1994 - 2003. Atmospheric Environment, 40, 166-177.

- Soukup, P. (2001). ISSP: životní prostředí. : Sociologický ústav Akademie věd České republiky.

- Vadala, C. E., Bixler, R. D., \& James, J. J. (2007). Childhood Play and Environmental Interest: Panacea of Snake Oil. The Journal of Environmental Education,39(1), 3-8.

- Yavetz, B., \& Goldman, D. (2009). A pE'ER, s. Environmental literacy of pre-service teachers in Israel: a comparison between students at the onset and end of their studies. Environmental Education Research, 4, 393-415. Retrieved from http://www.tandfonline.com/doi/abs/10.1080/13504620902928422 http://dx.doi.org/10.1080/13504620902928422

- YE, Z.N., Barker, S., Rowell, P., Reyes, P., Zhou, J.Z., Jenkins, F., Wang, M., Fuentes, E.L., (2008). Globalization of science inquiry and education for sustainable development . MBE 2008: Asia - Pacific conference on mind brain and education. : MBE 2008: Asia - Pacific conference on mind brain and education.

- Zoller, U. (2012). Science Education for global Sustainability: What Is Necessary for Teaching, Learning and Assessment Strategies. J. Chem. Educ, 89(3), 297-30.

\section{Příloha:} oblasti

Kompozice testu environmentální gramotnosti v návaznosti na základní sledované

\begin{tabular}{|c|c|c|}
\hline $\begin{array}{l}\text { Část } \\
\text { testu }\end{array}$ & Vybrané otázky & Oblast testování \\
\hline (a) & Otázka č. 1: Jakou střední školu jste absolvovali? & Pozad'ová data \\
\hline \multirow{2}{*}{ (b) } & Otázka č. 2: Jaká zvířata jste doma chovali / chováte? & $\begin{array}{l}\text { Environmentální } \\
\text { senzitivita (DOV) }\end{array}$ \\
\hline & Otázka č. 3: Jak často pobýváte $v$ př́rodě? & $\begin{array}{l}\text { Environmentální } \\
\text { senzitivita (DOV }\end{array}$ \\
\hline (c) & $\begin{array}{l}\text { Otázka č. 4: Uvedte, jak často: } \\
\text { Tř́díte odpad } \\
\text { Kupujete EKO výrobky }\end{array}$ & Akční strategie (DOV) \\
\hline
\end{tabular}




\begin{tabular}{|c|c|c|}
\hline & $\begin{array}{l}\text { Kupujete BIO výrobky } \\
\text { Se zapojujete do proenvironmentálních akcí } \\
\text { Upřednostňujete koupi českých výrobků před } \\
\text { zahraničními }\end{array}$ & \\
\hline \multirow{3}{*}{ (d) } & $\begin{array}{l}\text { Otázka č. 5: Vypište co nejvíc příkladů vztahů mezi } \\
\text { rostlinami a atmosférou }\end{array}$ & Zákonitosti (DOV) \\
\hline & Otázka č. 6: Čím vším může člověk urychlit erozi hornin? & Zákonitosti (DOV) \\
\hline & $\begin{array}{l}\text { Otázka č. 7: Ve 3-5 větách popište, co rozumíte pod } \\
\text { pojmem "trvale udržitelný rozvoj"? }\end{array}$ & Zákonitosti (DOV) \\
\hline (e) & $\begin{array}{l}\text { Otázka č. 8: Plánujete pokus pro děti z přírodovědného } \\
\text { kroužku. Očíslujte podle správného pořadí jednotlivé etapy } \\
\text { průběhu pokusu: } \\
\text { - Konfrontace vlastních zjištění se zjištěními ostatních } \\
\text { - Získávání a třídění informací o problému } \\
\text { - Vyhledání informačních zdrojů ke zkoumané problematice } \\
\text { Formulace hypotézy } \\
\text { Vyvození závěrů } \\
\text { Sestavení metodiky pokusu } \\
\text { Testování hypotézy } \\
\text { - Aplikace zjištěných závěrů do praktického života } \\
\text { Potvrzení nebo vyvrácení hypotézy }\end{array}$ & $\begin{array}{l}\text { BOV, } \quad \text { Výzkumné } \\
\text { dovednosti (DOV) }\end{array}$ \\
\hline
\end{tabular}

\section{Poděkování:}

Tento př́spěvek vznikl s podporou projektu GA JU č.065/2010/S

Mgr. Simona Dvořáčková, Ph.D. Zaměření: geologie. Působiště: Katedra biologie Pedagogická fakulta Jihočeská univerzita v Českých Budějovicích. E-mail: skralickova@pf.jcu.cz

Mgr. Renata Ryplová, Dr. Zaměření: fyziologie a ekologie rostlin, botanika. Působiště: Katedra biologie Pedagogická fakulta Jihočeská univerzita v Českých Budějovicích. E-mail: ryplova@pf.jcu.cz 
Časopis Envigogika vydává Centrum pro otázky životního prostředí UK. Vývoj časopisu je podpořen projektem OP VK Mezioborová sít udržitelného rozvoje.

Více najdete na internetových stránkách projektu http://mosur.czp.cuni.cz
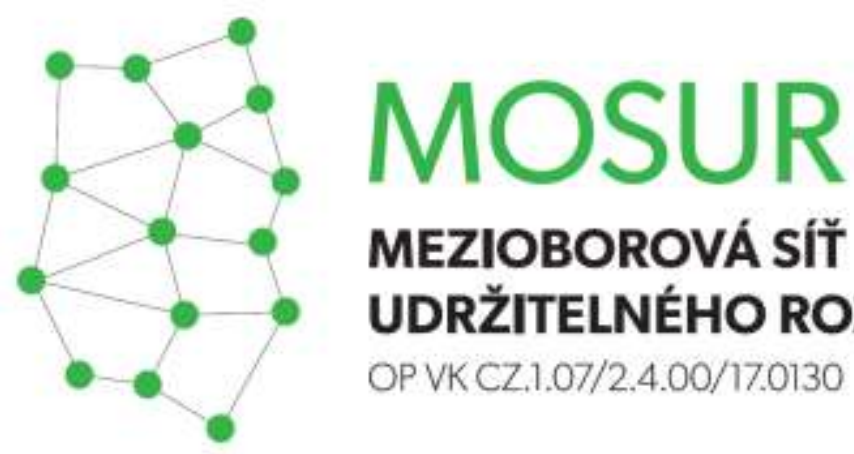

\section{MEZIOBOROVÁ SÍT}

UDRŽITELNÉHO ROZVOJE

OP VK CZ.1.07/2.4.00/17.0130
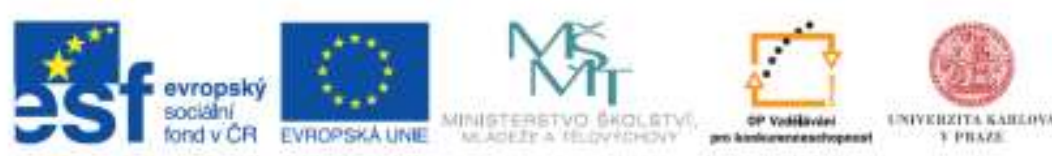

INVESTICE DO ROZVOJE VZDELAVANI 